Artikel Penelitian

\title{
PEMBELAJARAN SEJARAH INDONESIA DI SMAN 1 MALANG DALAM MENGEMBANGKAN KEMAMPUAN BERPIKIR HISTORIS
}

\author{
Siti Faizatun Nisa'1 ${ }^{1}$, Joko Sayono ${ }^{1}$, Indah Wahyu Puji Utami ${ }^{1,2}$ \\ faizahnisa12@gmail.com, joko.sayono.fis@um.ac.id, nie19.iwpu@e.ntu.edu.sg \\ Prodi Pendidikan Sejarah, Universitas Negeri Malang ${ }^{1}$ \\ National Institute of Education, Nanyang Technological University ${ }^{2}$

\begin{abstract}
Indonesian history learning curriculum hopes student historical thinking ability can be developed after the learning occured. Discussion focus of this article is history learning process in SMA N 1 Malang and student historical thinking ability. This research uses qualitative descriptive method. Research process is done by looking for data about research focus. The gotten data then explained and analyzed to explain research focus. Conclusion in this research is history learning in SMA N 1 Malang is in accordance with the valid curriculum. History learning that occures also able to develop student historical thinking ability. Through research instrument that is modified from Seixas's six hisrorical thinking component, it is known that student able to think historically.
\end{abstract}

Key words: history learning, historical thinking, student

\section{PENDAHULUAN}

Pembelajaran sejarah termasuk pembelajaran yang diterima siswa di jenjang Sekolah Menengah Atas (SMA). Salah satu aspek penting dalam pembelajaran Sejarah adalah adanya kemampuan berpikir historis. Menurut Monte-Sano \& Reisman dalam Bertram dkk (2017:3):

Scholars in Europe and in the Anglophone world define historical thinking as a familiarity and facility with disciplinary ways of interpreting and reasoning with historical texts, an appreciation of the slippery nature of historical knowledge, and the application of conceptual, narrative, and factual knowledge.

Berdasarkan penjelasan di atas, berpikir historis pada dasarnya merupakan kemampuan siswa untuk menafsirkan masa lalu menjadi sebuah sejarah. Peristiwa di masa lalu yang tersusun menjadi fakta-fakta perlu mendapat penafsiran-penafsiran tertentu sehingga akhirnya menjadi sebuah sejarah. Proses penyusunan peristiwa masa lalu menuju sejarah tersebut memerlukan kemampuan berpikir historis.

Seixas (2017:593) menyatakan bahwa kemampuan berpikir historis memiliki peranan penting dalam pendidikan sejarah baik dalam ranah teori maupun praktik. Oleh 
sebab itu, guru sejarah setidaknya harus mengajarkan kemampuan berpikir historis untuk melihat perkembangan siswa dalam pembelajaran sejarah. Komponen berpikir historis menurut Seixas seharusnya bisa menjadikan siswa memiliki 6 kemampuan yaitu: establish historical significance (menentukan signifikansi sejarah), use primary source evidence (menggunakan sumber primer sebagai bukti), identify change and continuity (mengidentifikasi perubahan dan keberlanjutan), analyze cause and consequence (menganalisis sebab-akibat), take historical perspective (menarik perspektif sejarah), dan understand ethical dimension (memahami dimensi etis) (Seixas, 2006:1).

Berpikir historis juga tercantum dalam kurikulum pembelajaran Sejarah di Indonesia. Berdasarkan silabus matapelajaran Sejarah dari Kementerian Pendidikan dan Kebudayaan (Kemendikbud) (2017:2), dapat dilihat bahwa salah satu tujuan diselenggarakannya pembelajaran sejarah di SMA dan sederajat adalah untuk mengembangkan kemampuan berpikir historis siswa. Siswa diharapkan memiliki kemampuan berpikir kritis termasuk dalam pembelajaran sejarah. Melalui pembelajaran langsung dapat dikembangkan pengetahuan, kemampuan berpikir, dan keterampilan menggunakan pengetahuan melalui interaksi langsung dengan sumber belajar yang menghasilkan pengetahuan dan keterampilan langsung (instructional effect) (Kementerian Pendidikan dan Kebudayaan (Kemendikbud) (2017:2).

Materi mengenai kemampuan berpikir historis dalam kurikulum dapat dijumpai di kelas X pada matapelajaran Sejarah Indonesia. K.D. 3.1, K. D. 4.1, K. D. 3.2, dan K. D. 4.2 berisi materi seputar kemampuan berpikir historis. Materi yang disampaikan tentang konsep berpikir kronologis, diakronis, sinkronis, serta konsep perubahan dan keberlanjutan dalam sejarah.

SMA N 1 Malang termasuk lembaga sekolah yang sudah menyelenggarakan pembelajaran Sejarah sesuai dengan Kurikulum 2013 revisi 2017. Terdapat matapelajaran Sejarah baik Sejarah Indonesia maupun Sejarah kelompok peminatan di sana. Selain itu SMA N 1 Malang juga sudah menerapkan kurikulum berbasis Sistem Kredit Semester (SKS) dengan menggunakan Unit Kegiatan Belajar Mandiri (UKBM) sebagai panduan belajar siswa.

Dalam pembelajaran Sejarah di SMA N 1 Malang, UKBM termasuk bagian dari bahan ajar yang disusun pada tahap perencanaan pembelajaran. UKBM seharusnya bisa menjadi sarana untuk melatih kemampuan berpikir historis siswa. Akan tetapi berdasarkan pengamatan awal peneliti terhadap dokumen UKBM yang disusun guru untuk matapelajaran Sejarah Indonesia di kelas XI, belum mencantumkan secara eksplisit mengenai kegiatan berpikir historis.

Berdasarkan penuturan guru Sejarah Indonesia di kelas XI (Ibu Ratnawati), gambaran awal kemampuan berpikir historis siswa dapat dilihat sebagai berikut. 
"Anak-anak itu kalau pengetahuan tentang berpikir kronologis, diakronis, sinkronis sudah paham. Mereka juga mengerti rangkaian peristiwa lalu sebab akibatnya seperti apa. Tapi untuk berpikir sejarah yang lebih kompleks seperti mengkritisi sumber sejarah kemudian menafsirkan itu masih belum bisa. Saya sudah mengusahakan agar anak-anak membaca dari banyak sumber, tapi kenyataannya mereka lebih suka menggunakan internet untuk memperoleh informasi. Padahal informasi di internet itu masih dipertanyakan kevalidannya, kita juga tidak tahu penulis menulis menggunakan perspektif apa. Nah, anak-anak masih belum bisa memilah-milah informasi yang sesuai. Anak-anak baru bisa mencerna peristiwa sederhana dengan analisis yang sederhana juga. Meski kemampuan berpikir historisnya anak-anak kurang, tapi tetap perlu diupayakan untuk meningkat. Saya berusaha membiasakan anakanak untuk menarasikan suatu peristiwa, kan itu sesuai dengan K. D. yang keterampilan". (wawancara tanggal 26 November 2018).

Berdasarkan pemaparan di atas diketahui bahwa setidaknya siswa masih belum terbiasa menggunakan sumber primer. Selain itu siswa belum mengerti konteks dan perspektif dalam sejarah. Melalui observasi awal tersebut baru dapat diidentifikasi 2 keterampilan berpikir historis menurut model big six yakni mengidentifikasi perubahan dan keberlanjutan serta menganalisis sebab-akibat. Penelitian ini berusaha mencari tahu mengapa siswa di SMA N 1 Malang belum memiliki kemampuan berpikir historis yang kompleks. Selain itu penelitian ini berusaha memotret apakah proses pembelajaran Sejarah di SMA N 1 Malang sudah dilaksanakan sesuai dengan tuntunan kurikulum sehingga bisa mengembangkan kemampuan berpikir historis siswa. Selanjutnya peneliti akan melihat kemampuan berpikir historis siswa menggunakan enam komponen milik Peter Seixas.

Penelitian ini akan dilakukan di kelas XI MIPA 8, XI IIS, serta XI Bahasa. Pemilihan ketiga kelas tersebut mewakili siswa dari masing-masing jurusan sehingga dapat diperoleh informasi yang beragam dan lengkap. Selain itu siswa di setiap jurusan tentu memiliki karakteristik yang berbeda-beda. Proses pembelajaran di ketiga kelas tersebut juga menggambarkan kemampuan berpikir historis siswa dalam matapelajaran Sejarah Indonesia.

Fokus dalam penelitian ini ada 2 hal. Pertama memaparkan proses pembelajaran sejarah Indonesia di SMA N 1 Malang. Kedua mengungkapkan kemampuan berpikir historis siswa di SMA N 1 Kota Malang. Berdasarkan paparan di atas, peneliti tertarik untuk meneliti "Proses Pembelajaran Sejarah Indonesia di SMA N 1 Malang dalam Mengembangkan Kemampuan Berpikir Historis Siswa". 


\section{METODE PENELITIAN}

Metode yang digunakan dalam penelitian ini adalah kualitatif deskriptif. Pertama peneliti melakukan analisis masalah. Setelah masalah diperoleh, peneliti mulai melakukan pencarian data. Teknik yang digunakan untuk mengumpulkan data dalam penelitian ini adalah wawancara dan observasi. Setelah data yang diperoleh dirasa cukup selanjutnya dilakukan analisis data dan pengecekan keabsahan temuan (Moleong, 2011:173-174).

\section{HASIL DAN PEMBAHASAN}

Proses pembelajaran sesuai dengan Permendikbud nomor 22 tahun 2016 tentang standar proses pendidikan meliputi perencanaan, pelaksanaan, dan evaluasi pembelajaran. Kegiatan perencanaan pembelajaran di SMA N 1 Malang meliputi penyusunan silabus, RPP, dan UKBM. Hal tersebut sudah sesuai dengan tuntunan dari Kurikulum 2013 revisi 2017. Stuktur isi RPP milik guru subyek sudah sesuai dengan struktur yang terdapat dalam Permendikbud nomor 22 tahun 2016.

Model pembelajaran yang dipilih guru subyek dalam merencanakan pembelajaran adalah problem based learning. Model pembelajaran tersebut dapat mendorong keaktivan siswa selama pelaksanaan pembelajaran. Siswa diberi permasalahan yang harus diselesaikan dengan cara mencari informasi dan berdiskusi. Proses pencarian informasi dan diskusi bisa mengembangkan budaya membaca dan menulis pada siswa. Berdasarkan hasil wawancara dengan guru subyek, RPP yang disusun turut memerhatikan tingkatan kognitif siswa. Prinsip penyusunan RPP mencakup hal-hal seperti keaktivan siswa, pengembangan budaya membaca menulis, serta kemampuan awal siswa.

Pelaksanaan pembelajaran sejarah merupakan sarana yang tepat untuk mengembangkan kemampuan berpikir historis siswa. Mengingat dalam buku untuk guru dari Kemendikbud tahun 2017 disebutkan bahwa matapelajaran Sejarah Indonesia merupakan kajian tentang sejarah Indonesia dengan menerapkan cara berpikir sejarah. Berdasarkan data yang diperoleh, bisa disimpulkan bahwa komponen-komponen berpikir historis milik Peter Seixas sudah muncul dalam pelaksanaan pembelajaran Sejarah di SMA N 1 Malang.

Peneliti menemukan adanya komponen-komponen berpikir historis melalui interaksi antara guru subyek dan siswa selama pembelajaran. Guru subyek sering memancing siswa untuk berpikir historis lewat pertanyaan-pertanyaan atau permasalahan yang diajukan. Cara lain yang dilakukan guru subyek adalah dengan menjelaskan kepada siswa serta memberikan penguatan terhadap hasil diskusi siswa. 
Rangsangan yang diberikan oleh guru subyek mampu ditanggapi siswa sehingga kemampuan berpikir historis digunakan untuk mengaji materi yang sedang dibahas. Melalui pelaksanaan pembelajaran kemampuan berpikir historis siswa dapat berkembang. Akan tetapi komponen penggunaan sumber primer sama sekali belum muncul dalam pelaksanaan pembelajaran. Sumber belajar yang dianjurkan guru untuk dipakai siswa masih terbatas kepada sumber-sumber sekunder. Guru subyek mengarahkan siswa untuk mencari informasi melalui buku sejarah, buku paket, dan internet. Kemudahan akses buku paket dan internet turut mendukung belum digunakannya sumber primer selama pelaksanaan pembelajaran.

Data yang diperoleh menunjukkan bahwa evaluasi pembelajaran sejarah di SMA N 1 Malang dilakukan dengan beberapa teknik. Evaluasi yang dilakukan mencakup aspek sikap, pengetahuan, dan keterampilan. Selama pembelajaran berlangsung, guru subyek melakukan penilaian terhadap siswa. Begitu pula di akhir pembelajaran dilakukan tes melalui ulangan harian. Nilai yang diperoleh dari berbagai komponen tersebut yang kemudian dijadikan pertimbangan untuk menentukan hasil evaluasi akhir.

Panduan penilaian yang digunakan guru subyek terdapat dalam RPP. Pada praktiknya, panduan tersebut memang digunakan guru subyek selama proses pembelajaran. Oleh sebab itu dapat disimpulkan bahwa evaluasi pembelajaran sejarah di SMA N 1 Malang sudah mengikuti pedoman dalam Permendikbud nomor 22 tahun 2016.

Proses pembelajaran sejarah yang berlangsung di SMA N 1 Malang tentu memiliki hubungan dengan pengembangan kemampuan berpikir historis siswa. Pembelajaran sejarah di Indonesia diselenggarakan dengan harapan agar siswa bisa memelajari peristiwa di masa lalu dengan menerapkan kemampuan berpikir historis. Berpikir historis merupakan bagian dari keterampilan yang harus dikembangkan saat siswa belajar Sejarah Indonesia (buku guru dari Kemendikbud tahun 2017). Berpikir historis yang disebutkan dalam Kurikulum 2013 edisi revisi 2017 untuk matapelajaran Sejarah Indonesia mencakup kemampuan siswa menggunakan berpikir kronologis, diakronik, sinkronik, konsep sejarah seperti perubahan (change), keberlanjutan (continuity), serta hukum sebab-akibat dalam mempelajari peristiwa sejarah. Komponen-komponen tersebut diajarkan melalui K.D.

\section{1, 4.1, 3.2, dan 4.2 matapelajaran Sejarah Indonesia untuk siswa kelas X.}

Teori lain tentang berpikir historis yang banyak digunakan di dunia internasional di antaranya ialah milik Peter Seixas. Oleh karena teori Seixas memiliki 6 komponen maka disebut sebagai the big six. Seixas dan Morton (2013:10) menyatakan bahwa konsep berpikir historis memiliki 6 unsur. Pertama yaitu historical significance (makna sejarah), kedua mengenai evidence (bukti), ketiga change and continuity (perubahan dan keberlanjutan), keempat cause and consequence (sebab-akibat), kelima historical perspective (perspektif sejarah), dan keenam ethical dimension (dimensi etis). 
Penelitian ini menggunakan the big six sebagai pedoman untuk melihat kemampuan berpikir historis siswa. Masing-masing komponen memiliki indikator yang lebih rinci untuk menjelaskan bagaimana berpikir historis sebenarnya. Melalui keenam komponen beserta indikator, kemampuan berpikir historis siswa dapat diungkap secara lebih luas dan komperhensif. Penjelasan mengenai kemampuan berpikir historis siswa di SMA N 1 Malang akan dipaparkan sebagai berikut.

\section{Kebermaknaan sejarah}

Kebermaknaan sejarah berkaitan dengan bagaimana seseorang menentukan bahwa suatu peristiwa di masa lalu penting dan bermakna. Indikator dari kebermaknaan sejarah adalah apabila suatu peristiwa menghasilkan perubahan, dapat menjelaskan isuisu sejarah, serta memiliki kedudukan berarti dalam narasi (Seixas \& Morton, 2013:10). Data yang diperoleh menjelaskan bahwa kebermaknaan sejarah menurut siswa berhubungan dengan peristiwa yang menghasilkan perubahan serta bisa memberikan pelajaran berharga.

Indikator yang belum nampak dari pernyataan-pernyataan siswa adalah peristiwa bermakna karena memiliki kedudukan penting dalam narasi. Menurut peneliti hal tersebut dikarenakan siswa memang terbiasa memelajari peristiwa-peristiwa sejarah yang sudah dipilih untuk dimasukkan dalam kurikulum. Sedangkan siswa hampir tidak pernah diberi penjelasan mengapa di antara banyaknya peristiwa di masa lalu, dipilih beberapa peristiwa saja untuk mereka pelajari di sekolah.

\section{Penggunaan sumber primer}

Salah satu komponen berpikir historis menurut Seixas adalah evidence (bukti) yang berasal dari sumber primer. Menurut Seixas \& Morton (2013:10) sejarah lahir dari interpretasi terhadap sumber. Penggunaan sumber primer sebagai bukti sejarah memiliki rambu-rambu yang dapat digunakan untuk mengkritisi keabsahan sumber tersebut. Sumber primer yang digunakan harus dianalisis pemiliknya, dianalisis konteks waktunya, serta perlu digunakan sumber pembanding.

Data yang diperoleh menunjukkan bahwa siswa belum menggunakan sumber primer selama pembelajaran sejarah di kelas XI. Siswa banyak diarahkan untuk mengumpulkan informasi melalui buku sejarah, buku paket, dan internet. Baik selama kegiatan belajar mengajar maupun ketika mengerjakan UKBM, sumber yang dominan digunakan siswa adalah internet. Akses yang mudah dan praktis menyebabkan siswa senang menggunakan internet untuk mengerjakan tugas dan mencari informasi selama pembelajaran. Selain itu siswa memang belum diberi kesempatan khusus untuk menggunakan sumber primer sebagai rujukan saat belajar sejarah. Mengingat hampir 
keseluruhan sumber primer yang sesuai untuk materi yang sedang dipelajari siswa tersedia di luar sekolah.

Siswa nampaknya juga belum terbiasa untuk mengkritisi dan menyaring informasi yang diperoleh dari internet. Situs-situs tentang sejarah yang tersedia di internet belum dimanfaatkan dengan baik. Siswa memilih situs secara acak di internet untuk mendapatkan informasi tentang materi sejarah yang sedang dipelajari.

\section{Keberlanjutan dan perubahan}

Salah satu kemampuan berpikir historis yang disebutkan dalam Kurikulum 2013 revisi 2017 untuk matapelajaran Sejarah Indonesia adalah keberlanjutan dan perubahan. Seixas \& Morton (2013:11) menyatakan beberapa indikator untuk keberlanjutan dan perubahan. Indikator yang dimaksud adalah kronologi, proses perubahan, kemajuan dan kemunduran, serta periodesasi.

Data-data yang ada menjelaskan bahwa indikator keberlanjutan dan perubahan yang muncul selama penelitian adalah kronologi, proses perubahan, serta periodesasi. Indikator yang paling sering muncul adalah kronologi dan proses perubahan, sedangkan periodesasi hanya muncul satu kali. Berpikir kronologis juga menjadi bagian dari kemampuan berpikir historis yang tercantum dalam kurikulum.

Siswa menyatakan bahwa di masa lalu terjadi perubahan dari peristiwa satu ke peristiwa lain dan terdapat sesuatu yang berlanjut dari peristiwa tersebut. Pemahaman tersebut memang sesuai dengan penjelasan yang ada di dalam buku pegangan guru dari Kemendikbud untuk matapelajaran Sejarah Indonesia, sesuai dengan Kurikulum 2013 revisi 2017. Indikator kronologi, proses perubahan, serta periodesasi sudah tercakup dalam penjelasan tersebut. Akan tetapi untuk indikator kemajuan dan kemunduran masih belum tampak baik dari data observasi maupun wawancara. Oleh karena konsep kemajuan dan kemunduran dalam sejarah nampaknya memang belum diajarkan kepada siswa.

\section{Sebab Akibat}

Komponen berpikir historis lain yang disebutkan dalam kurikulum adalah sebab akibat. Perubahan yang terjadi memiliki beragam sebab serta akibat yang beragam pula. Sebab suatu peristiwa sejarah dapat dikelompokkan menjadi dua. Pertama sebab berupa pelaku sejarah dan yang kedua sebab berupa kondisi-kondisi seperti sosial, ekonomi, politik, dan budaya yang menyebabkan terjadinya suatu peristiwa (Seixas dan Morton, 2013: 11).

Buku pegangan guru dari Kemendikbud menyatakan bahwa setiap peristiwa sejarah yang terjadi tentu memiliki sebab serta menimbulkan akibat. Pernyataan tersebut sesuai dengan penjelasan siswa saat ditanyai tentang sebab akibat. Data yang ditemukan 
melalui observasi juga menunjukkan bahwa siswa menjelaskan suatu peristiwa sejarah dengan terlebih dahulu menyebutkan penyebabnya, kemudian akibatnya. Penyebab peristiwa sejarah yang disebutkan siswa mencakup baik pelaku sejarah maupun kondisi.

\section{Perspektif sejarah}

Perspektif sejarah berkaitan dengan bagaimana seseorang di masa kini seharusnya memandang peristiwa di masa lalu. Agar bisa memahami sejarah dengan baik maka perlu diperhatikan konteks yang ada. Indikator dari komponen ini yang pertama adalah seseorang dapat memahami konteks pelaku dan situasi peristiwa sejarah. Kedua, seseorang dapat memahami perbedaan perspektif terhadap suatu peristiwa (Seixas \& Morton, 2013:11).

Data-data yang didapatkan menunjukkan bahwa siswa sudah dapat melihat peristiwa di masa lalu sesuai dengan situasi dan kondisi masa itu. Siswa dapat menjelaskan mengapa suatu peristiwa terjadi dengan mengaitkan kepada konteks yang ada. Berkenaan dengan indikator yang kedua, siswa dapat memahami jika setiap pelaku sejarah memiliki pandangan yang berbeda-beda atas suatu peristiwa. Oleh sebab itu wajar jika terjadi peristiwa-peristiwa yang diakibatkan oleh adanya perbedaan pendapat antarpelaku sejarah.

\section{Dimensi etis}

Komponen berpikir historis yang terakhir menurut Peter Seixas \& Tom Morton adalah dimensi etis. Komponen ini berhubungan dengan nilai yang dapat diambil dari peristiwa masa lalu. Namun yang perlu dipahami adalah tidak selamanya nilai yang ada di masa sekarang dapat disamakan dengan nilai yang dianut manusia zaman dahulu (Seixas \& Morton, 2013:11).

Berdasarkan data yang diperoleh, diketahui bahwa siswa dapat mengambil nilainilai dari peristiwa sejarah. Nilai-nilai sejarah yang disampaikan siswa sebagian besar berkaitan dengan perjuangan bangsa Indonesia hingga bisa sampai ke tahap saat ini. Siswa juga menyebutkan bahwa nilai-nilai yang ada harus diupayakan untuk diterapkan di masa kini. Akan tetapi siswa belum menjelaskan mengenai nilai-nilai yang berbeda di masa lalu dan masa sekarang. Siswa fokus menjelaskan nilai-nilai perjuangan yang relevan dengan situasi saat ini karena materi yang baru dipelajari siswa memang seputar perjuangan bangsa Indonesia untuk meraih kemerdekaan.

Terdapat 5 komponen berpikir historis yang sudah dimiliki siswa meski beberapa indikator belum terpenuhi. Secara keseluruhan 5 komponen tersebut sudah berhasil diterapkan siswa ketika memelajari peristiwa sejarah tertentu. Satu komponen yang sama sekali belum nampak adalah penggunaan sumber primer. Baik dalam kurikulum maupun 
dalam praktik pembelajaran, penggunaan sumber primer memang belum ditekankan. Siswa lebih sering dikenalkan dengan buku-buku sejarah maupun buku paket serta sumber lain yang bisa diakses melalui internet.

Berpikir historis yang dicantumkan dalam kurikulum lebih sederhana dibandingkan berpikir historis yang dicetuskan oleh Peter Seixas. Komponen-komponen yang diciptakan oleh Seixas sebenarnya bisa mendeteksi kemampuan berpikir historis siswa secara lebih mendalam. Terlebih komponen berpikir historis yang dijelaskan dalam kurikulum sebenarnya juga bagian dari the big six milik Peter Seixas. Oleh karena itu, komponenkomponen yang dominan dipahami siswa adalah komponen yang disebutkan dalam kurikulum seperti keberlanjutan dan perubahan, serta sebab akibat. Sedangkan penggunaan sumber primer memang belum familiar di kalangan siswa.

Meski begitu, kelima komponen yang sudah dimunculkan menunjukkan bahwa siswa mampu berpikir historis sesuai dengan komponen-komponen milik Peter Seixas. Proses pembelajaran sejarah Indonesia yang berlangsung di SMA N 1 Malang sudah berhasil mengembangkan kemampuan berpikir historis siswa. Hal tersebut bisa tercapai karena adanya dukungan dari berbagai elemen seperti sarana prasarana serta keberadaan guru sejarah yang memadahi. Kondisi semacam itu tentu perlu dipertahankan dan terus dievaluasi agar selalu ada peningkatan.

\section{SIMPULAN}

Proses pembelajaran Sejarah di SMA N 1 Malang telah sesuai dengan Permendikbud nomor 22 tahun 2016 tentang standar proses pendidikan dasar dan menengah. Perencanaan pembelajaran di SMA N 1 Malang meliputi penyusunan RPP dan UKBM. Terdapat kesinambungan antara RPP dan UKBM yang digunakan sebagai panduan dalam pelaksanaan pembelajaran. Pada tahap pelaksanaan pembelajaran, aspek yang belum maksimal adalah penggunaan media pembelajaran. Proses evaluasi pembelajaran dilakukan dengan berbagai teknik untuk melihat hasil belajar dari ranah sikap, pengetahuan, dan keterampilan. Proses pembelajaran Sejarah Indonesia yang berlangsung di SMA N 1 Malang sudah memuat upaya bagi pengembangan kemampuan berpikir historis siswa.

Kemampuan berpikir historis siswa di SMA N 1 Malang sudah mencapai 5 dari 6 komponen berpikir historis milik Peter Seixas. Sebagian besar indikator dari komponenkomponen yang ada sudah ditemukan pada siswa. Satu komponen yang sama sekali belum ada pada siswa yaitu penggunaan sumber primer. Siswa menggunakan sumber-sumber sekunder seperti buku dan internet untuk mengumpulkan informasi terkait peristiwa sejarah yang sedang dipelajari. 
Berdasarkan kesimpulan di atas maka peneliti mengajukan saran-saran sebagai berikut. Pembelajaran sejarah yang dilakukan ke depan hendaknya dilaksanakan dengan lebih variatif. Media pembelajaran yang digunakan tidak hanya terbatas pada media-media elektronik atau media berbasis teknologi informasi namun juga bisa menggunakan media konvensional. Benda-benda seperti peta, maket, dan pop up tentu dapat dimanfaatkan sebagai media pembelajaran. Selain contoh-contoh tersebut, masih banyak alternatif media lain yang dapat digunakan dalam pembelajaran.

\section{DAFTAR PUSTAKA}

Bertram, C., Wagner, W., Trautwein, U. 2017. Learning Historical Thinking With Oral History Interviews: A Cluster Randomized Controlled Intervention Study of Oral History Interviews in History Lessons. American Educational Research Journal, 54 (3): 444-484.

Moleong, L. J. 2011. Metodologi Penelitian Kualitatif edisi Revisi. Bandung: Remaja Rosda Karya.

Peraturan Menteri Pendidikan dan Kebudayaan Republik Indonesia Nomor 22 Tahun 2016 Tentang Standar Proses Pendidikan Dasar dan Menengah. BSNP (Online). (https://bsnp-indonesia.org). diakses 26 Januari 2019.

Seixas, P. 2006. Benchmark of Historical Thinking: A Framework for Assessment in Canada. Centre for The Study of Historical Consciousness UBC.

Seixas, P \& Morton, T. 2013. The Big Six: Historical Thinking Concepts. Toronto: Nelson Education Ltd.

Seixas, P. 2017. A Model of Historical Thinking. Jurnal Educational Philosophy and Theory, 49 (6): 593-605.

Silabus matapelajaran Sejarah Sekolah Menengah Atas/Madrasah Aliyah Kementerian Pendidikan dan Kebudayaan (Kemendikbud) Republik Indonesia Tahun 2017. Tulisan Guru (Online). (www.tulisanguru.com). diakses 26 Januari 2019. 